\title{
CLINICAL AND RADIOLOGICAL ASSESSMENT OF THE CONDITION OF IMPLANTS WITH FIXED STRUCTURES IN THE DYNAMICS OF 20-YEAR FOLLOW-UP
}

Olesov EE ${ }^{1}$, Ivanov $\mathrm{AS}^{2}$, Zaslavskiy $\mathrm{RS}^{2}$, Ragulin $A V^{1}$, Romanov $\mathrm{AS}^{2}$

Clinical Center of Dentistry of Federal Medical Biological Agency, Moscow, Russia

Burnasyan Federal Medical Biophysical Center of Federal Medical Biological Agency, Moscow, Russia

\begin{abstract}
The statistically significant long-term results of the implant survival and the effectiveness of prostheses are inadequately represented in scientific literature. The study was aimed to assess the effectiveness of prosthetics with fixed structures on the intraosseous dental implants for the replacement of partially absent dentition in the dynamics of the 20-year follow-up. A total of 671 patients with partially missing teeth were examined at the Clinical Center of Dentistry of the FMBA of Russia, who were fitted with 1,700 intraosseous titanium dental implants with the terms from the moment of completion of prosthetics on implants of $5,10,15$ or 20 years. The criteria for clinical and radiological evaluation of the implant condition were as follows: no complications affecting the condition of periimplant tissues (normal), mucositis, periimplantitis with bone resorption at $1 / 3$ or $1 / 2$ of the implant height, implant removal. Based on 20 years of experience, prosthetics with fixed structures on implants is highly effective in replacing the partial defects of dentition. In total, $62.2 \%$ of implants remain functional for 20 years. The average life of implant-supported fixed prostheses is 15 years for bridges, and 20 years for single and combined implant-supported crowns. The most effective are single implant-supported crowns, and the least effective are prostheses supported by implants and teeth. The significantly preserved implant-supported prostheses make it possible to support the concept of the long-term implant installation with respect to the implant-supported non-removable prostheses. The view is thus confirmed that the effectiveness of the implant-supported prosthetics is reduced with the inclusion of teeth in the bridge support, along with implants.
\end{abstract}

Keywords: dental implants, fixed prostheses, efficiency, 20-year follow-up

Author contribution: Olesov EE, Ivanov AS — clinical data collection and processing; Zaslavskiy RS, Ragulin AV — statistical analysis; Romanov AS — illustrations. Compliance with ethical standards: the study was approved by the Ethics Committee of the Clinical Center of Dentistry of the Federal Medical Biological Agency (protocol № 12 dated December 4, 2020). The informed consent was submitted by all study participants.

$\bowtie$ Correspondence should be addressed: Egor E. Olesov

Gamalei str. 15, bld. 1, Moscow, 123098, Russia; olesov_georgiy@mail.ru

Received: 29.10.2021 Accepted: 16.11.2021 Published online: 17.12.2021

DOI: $10.47183 /$ mes.2021.040

\section{КЛИНИКО-РЕНТГЕНОЛОГИЧЕСКАЯ ОЦЕНКА СОСТОЯНИЯ ИМПЛАНТАТОВ С НЕСЪЕМНЫМИ КОНСТРУКЦИЯМИ В ДИНАМИКЕ ЗА 20 ЛЕТ}

\author{
Е. Е. Олесов ${ }^{1 凶}$, А. С. Иванов², Р. С. Заславский르 А. В. Рагулин ${ }^{1}$, А. С. Романов²
}

Клинический центр стоматологии ФМБА России, Москва, Россия

Федеральный медицинский биофизический центр имени А. И. Бурназяна ФМБА России, Москва, Россия

\begin{abstract}
Статистически значимые результаты выживаемости имплантатов и эффективности протезов на имплантатах в отдаленные сроки недостаточно представлены в научной литературе. Целью исследования было изучить эффективность протезирования несъемными конструкциями на внутрикостных дентальных имплантатах при замещении частичных дефектов зубных рядов в динамике за 20 лет. В Клиническом центре стоматологии ФМБА России обследованы 671 пациент с частичным отсутствием зубов, которым были установлены 1700 внутрикостных титановых дентальных имплантатов со сроками с момента завершения протезирования на имплантатах 5, 10, 15 и 20 лет. Критериями клинико-рентгенологической оценки состояния имплантатов были состояние периимплантатных тканей без осложнений (нормальное), мукозит, периимплантит с резорбцией костной ткани на 1/3 или 1/2 высоты имплантата, удаление имплантата. Протезирование несъемными конструкциями на имплантатах, согласно 20-летнему опыту замещения частичных дефектов зубных рядов, характеризуется высокой эффективностью. В общей сложности 62,2\% имплантатов сохраняют функциональность в течение 20 лет. Средний срок функционирования несъемных протезов на имплантатах составляет 15 лет для мостовидных протезов и 20 лет - для одиночных и объединенных коронок на имплантатах. Наиболее эффективны одиночные коронки на имплантатах, наименее - протезы с опорой на имплантаты и на зубы. Значительная сохранность протезов на имплантатах позволяет поддержать концепцию долгосрочной установки имплантатов относительно несъемных протезов на имплантатах. Подтверждается мнение о снижении эффективности протезирования на имплантатах при включении в опору мостовидных протезов зубов, наряду с имплантатами.
\end{abstract}

Ключевые слова: дентальные имплантаты, несъемные протезы, эффективность, 20-летняя динамика

Вклад авторов: Е. Е. Олесов, А. С. Иванов - сбор и обработка клинического материала; Р. С. Заславский, А. В. Рагулин - статистический анализ; А. С. Романов - иллюстрации.

Соблюдение этических стандартов: исследование одобрено этическим комитетом ФГБУЗ «Клинический центр стоматологии» ФМБА России (протокол № 12 от 4 декабря 2020 г.). Все участники подписали добровольное информированное согласие на участие в исследовании.

$\triangle$ Для корреспонденции: Егор Евгеньевич Олесов

ул. Гамалеи, д. 15, корп. 1, г. Москва, 123098, Россия; olesov_georgiy@mail.ru

Статья получена: 29.10.2021 Статья принята к печати: 16.11.2021 Опубликована онлайн: 17.12.2021

DOI: $10.47183 /$ mes.2021.040

The dental implant treatment method is being actively introduced into dental practice in the Russian regions, particularly in the sectoral healthcare institutions [1-4]. The experience of using the dental implants as the intraosseous support for dental prostheses in Russia dates back several decades, however, the statistically significant long-term results of the implant survival and the effectiveness of the implant-supported prostheses are inadequately represented in scientific literature. This leads to discrepancies in advising the patients with indications for dental implant treatment, provided by different dentists, as well as in teaching the clinical residents, and advanced training of dentists. 
The efficiency of prosthetics on implants depends on the clinical settings, especially on the full or partial absence of dentition, the prosthesis design (including the number of supporting implants), and the prosthesis lifespan [5-13].

In practice, the implant removal due to mobility, resulting from the surrounding bone tissue resorption, is the main criterion for evaluating the implant condition, however, the timely prevention of periimplant inflammation and the implant overloading requires a more detailed evaluation of periimplant tissue.

In the Clinical Center of Dentistry of the FMBA, the dental implant treatment has been used as the main method for the complex dental rehabilitation of patients with partially missing teeth for 20 years. A wealth of experience has been gained in the dynamic analysis of longitudinal data on the dental implant condition depending on the prosthetic method in acordance with the international assessment criteria.

The study was aimed to assess the effectiveness of prosthetics with fixed structures on the intraosseous dental implants for the replacement of partially absent dentition in the dynamics of the 20-year follow-up.

\section{METHODS}

A total of 671 patients were examined, who were fitted with 1,700 intraosseous titanium dental implants. Among the patients there were 379 females and 292 males, and the average age of the patients was 26-81 years (149 individuals under the age of 40, 318 individuals aged 40-60, 204 individuals over the age of 60 ). Inclusion criteria: non-removable prostheses on implants, the term from the moment of the implant installation and prosthetics completion exceeding 5 years. Exclusion criteria: the presence of dental implants and removable prostheses; the service life of implant-supported prostheses of less than 5 years; the implants istalled in different healthcare provider organizations; the refusal of clinical and radiological examination. Based on the terms from the moment of the completion of prosthetics on implants, the patients were divided in the following way: 5 years -120 individuals, 10 years -130 individuals, 15 years -180 individuals, 20 years 241 individuals (the number of implants installed was 319, 405, 453 , and 52 , respectively).

In terms of the design, the fixed prostheses (number of individuals and supporting implants) were represented by single crowns (201 individuals, 501 implants), combined crowns (132 individuals, 321 implants), implant-supported bridges (285 individuals, 725 implants), bridges supported by implants and teeth (53 individuals, 153 implants).

The standard two-stage titanium intraosseous implant installation technique and the generally accepted method of fabricating the metal ceramic implant-supported fixed prostheses were used [14-15].

The majority of patients hardly ever contacted the dentist for professional oral hygiene or other follow-up care.

In accordance with the aim of the study, the criteria for evaluation of the implant condition were as follows: no complications affecting the condition of periimplant tissues (normal), mucositis, periimplantitis with bone resorption at $1 / 3$ or $1 / 2$ of the implant height, implant removal [16-18]. That is why the patients underwent orthopantomography in addition to the standard clinical examination of the teeth, periodontium, and implants.

Statistical processing of the results was performed by standard methods with the use of the Microsoft Excel software (Microsoft; USA).

\section{RESULTS}

After 5 years of functioning, the clinical and radiological assessment of the implant condition in the partial fixed dental prostheses revealed that normal condition, mucositis, periimplantitis with bone resorption at $1 / 3$ or $1 / 2$ of the implant height, and implant removal were found in 103, 76, 86, 33, and 21 implants, respectively, which accounted for $32.3 \%$, $23.8 \%, 27.0 \%, 10.4 \%$, and $6.6 \%$ of all the implants installed in this clinical settings (Table 1). In patients with single crowns on implants, the 5 -year period of functioning was characterized by $40.0 \%$ of implants with no complications (56 implants), mucositis in $20.0 \%$ of implants (28 implants), periimplantitis with bone resorption at $1 / 3$ of the implant height in $23.6 \%$ (33 implants), and at $1 / 2$ of the implant height in 10.7\% (15 implants), as well as by $5.7 \%$ of implants removed (8 implants). Based on the listed above criteria, the efficiency of the combined crowns was as follows: $31.0 \%$ (18 implants), 22.4\% (13 implants), 32.8\% (19 implants), 6.9\% (4 implants), 6.9\% (4 implants). After 5 years of loading, the implant-supported bridges showed no changes in the state of gums or bone tissue in $24.0 \%$ of observations (29 implants), mucositis was found in 28.9\% (35 implants), periimplantitis with bone resorption at $1 / 3$ was found in $28.1 \%$ (34 implants), periimplantitis with bone resorption at $1 / 2$ of the implant height was found in $11.6 \%$ (14 implants), and $7.4 \%$ of implants were removed (9 implants). Bridges supported by teeth and implants were no longer used 5 years ago.

After 10 years, the listed above indicators of the implant condition in partial fixed dental prostheses (normal condition, mucositis, periimplantitis with bone resorption at $1 / 3$ or $1 / 2$ of the implant height, and implant removal) accounted for $15.1 \%$ (61 implants), 23.2\% (94 implants), 25.2\% (102 implants), $12.6 \%$ (51 implants), and 24.0\% (97 implants), respectively.

Table 1. Clinical and radiological dental implant assessment results based on the prosthesis design and the term from the moment of installation (quantity, \%)

\begin{tabular}{|c|c|c|c|c|c|c|c|c|c|c|c|c|c|c|c|c|c|c|c|c|}
\hline \multirow{2}{*}{$\begin{array}{l}\text { Characteristics } \\
\text { Term (years) }\end{array}$} & \multicolumn{4}{|c|}{ No complications } & \multicolumn{4}{|c|}{ Mucositis } & \multicolumn{4}{|c|}{ Resorption at $1 / 3$} & \multicolumn{4}{|c|}{ Resorption at $1 / 2$} & \multicolumn{4}{|c|}{ Removed } \\
\hline & 5 & 10 & 15 & 20 & 5 & 10 & 15 & 20 & 5 & 10 & 15 & 20 & 5 & 10 & 15 & 20 & 5 & 10 & 15 & 20 \\
\hline Single crowns & $\begin{array}{c}56 \\
40.0\end{array}$ & $\begin{array}{c}27 \\
15.3\end{array}$ & - & - & $\begin{array}{c}28 \\
20.0\end{array}$ & $\begin{array}{c}25 \\
14.2\end{array}$ & $\begin{array}{c}10 \\
13.2\end{array}$ & $\begin{array}{c}4 \\
3.7\end{array}$ & $\begin{array}{c}33 \\
23.6\end{array}$ & $\begin{array}{c}61 \\
34.7\end{array}$ & $\begin{array}{c}27 \\
35.5\end{array}$ & $\begin{array}{c}29 \\
26.6\end{array}$ & $\begin{array}{c}15 \\
10.7\end{array}$ & $\begin{array}{c}23 \\
13.1\end{array}$ & $\begin{array}{c}7 \\
9.2\end{array}$ & $\begin{array}{c}20 \\
18.4\end{array}$ & $\begin{array}{c}8 \\
5.7\end{array}$ & $\begin{array}{c}40 \\
22.7\end{array}$ & $\begin{array}{c}29 \\
38.2\end{array}$ & $\begin{array}{c}56 \\
51.4\end{array}$ \\
\hline $\begin{array}{l}\text { Combined } \\
\text { crowns }\end{array}$ & $\begin{array}{c}18 \\
31.0\end{array}$ & $\begin{array}{c}15 \\
18.5\end{array}$ & - & - & $\begin{array}{c}13 \\
22.4\end{array}$ & $\begin{array}{c}24 \\
29.6\end{array}$ & $\begin{array}{c}16 \\
17.8\end{array}$ & $\begin{array}{c}2 \\
2.2\end{array}$ & $\begin{array}{c}19 \\
32.8\end{array}$ & $\begin{array}{c}10 \\
12.4\end{array}$ & $\begin{array}{c}29 \\
32.2\end{array}$ & $\begin{array}{c}27 \\
29.4\end{array}$ & $\begin{array}{c}4 \\
6.9\end{array}$ & $\begin{array}{c}13 \\
16.1\end{array}$ & $\begin{array}{c}9 \\
10.0\end{array}$ & $\begin{array}{c}15 \\
16.3\end{array}$ & $\begin{array}{c}4 \\
6.9\end{array}$ & $\begin{array}{c}19 \\
23.5\end{array}$ & $\begin{array}{c}36 \\
40.0\end{array}$ & $\begin{array}{c}48 \\
52.2\end{array}$ \\
\hline Bridges & $\begin{array}{c}29 \\
24.0\end{array}$ & $\begin{array}{c}17 \\
15.6\end{array}$ & - & - & $\begin{array}{c}35 \\
28.9\end{array}$ & $\begin{array}{c}35 \\
32.1\end{array}$ & $\begin{array}{c}50 \\
21.9\end{array}$ & $\begin{array}{l}24 \\
9.0\end{array}$ & $\begin{array}{c}34 \\
28.1\end{array}$ & $\begin{array}{c}23 \\
21.1\end{array}$ & $\begin{array}{c}56 \\
24.5\end{array}$ & $\begin{array}{c}42 \\
15.7\end{array}$ & $\begin{array}{c}14 \\
11.6\end{array}$ & $\begin{array}{c}12 \\
11.0\end{array}$ & $\begin{array}{c}24 \\
10.5\end{array}$ & $\begin{array}{c}30 \\
11.2\end{array}$ & $\begin{array}{c}9 \\
7.4\end{array}$ & $\begin{array}{c}22 \\
20.2\end{array}$ & $\begin{array}{l}107 \\
46.9\end{array}$ & $\begin{array}{l}171 \\
64.1\end{array}$ \\
\hline $\begin{array}{l}\text { Combined with } \\
\text { teeth }\end{array}$ & - & $\begin{array}{c}2 \\
5.1\end{array}$ & - & - & - & $\begin{array}{c}10 \\
25.6\end{array}$ & $\begin{array}{c}10 \\
17.0\end{array}$ & - & - & $\begin{array}{c}8 \\
20.5\end{array}$ & $\begin{array}{c}8 \\
13.5\end{array}$ & - & - & $\begin{array}{c}3 \\
7.7\end{array}$ & $\begin{array}{c}12 \\
20.3\end{array}$ & - & - & $\begin{array}{c}16 \\
41.0\end{array}$ & $\begin{array}{c}23 \\
39.0\end{array}$ & $\begin{array}{l}55 \\
100\end{array}$ \\
\hline $\begin{array}{l}\text { Partially abscent } \\
\text { dentition }\end{array}$ & $\begin{array}{c}103 \\
32.3\end{array}$ & $\begin{array}{c}61 \\
15.1\end{array}$ & - & - & $\begin{array}{c}76 \\
23.8\end{array}$ & $\begin{array}{c}94 \\
23.2\end{array}$ & $\begin{array}{c}86 \\
19.0\end{array}$ & $\begin{array}{l}30 \\
5.7\end{array}$ & $\begin{array}{c}86 \\
27.0\end{array}$ & $\begin{array}{c}102 \\
25.2\end{array}$ & $\begin{array}{l}120 \\
26.5\end{array}$ & $\begin{array}{c}98 \\
18.7\end{array}$ & $\begin{array}{c}33 \\
10.4\end{array}$ & $\begin{array}{c}51 \\
12.6\end{array}$ & $\begin{array}{c}52 \\
11.5\end{array}$ & $\begin{array}{c}65 \\
12.4\end{array}$ & $\begin{array}{l}21 \\
6.6\end{array}$ & $\begin{array}{c}97 \\
24.0\end{array}$ & $\begin{array}{l}195 \\
43.1\end{array}$ & $\begin{array}{l}330 \\
63.1\end{array}$ \\
\hline
\end{tabular}


Table 2. Clinical and radiological dental implant assessment results based on the prosthesis design (quantity, \%)

\begin{tabular}{|c|c|c|c|c|c|}
\hline Characteristics & No complications & Mucositis & Resorption at $1 / 3$ & Resorption at $1 / 2$ & Removed \\
\hline Single crowns & $\begin{array}{c}83 \\
16.6\end{array}$ & $\begin{array}{c}68 \\
13.4\end{array}$ & $\begin{array}{l}150 \\
29.9\end{array}$ & $\begin{array}{c}66 \\
13.0\end{array}$ & $\begin{array}{l}133 \\
26.5\end{array}$ \\
\hline Combined crowns & $\begin{array}{c}33 \\
10.3\end{array}$ & $\begin{array}{c}55 \\
17.1\end{array}$ & $\begin{array}{c}85 \\
26.5\end{array}$ & $\begin{array}{c}41 \\
12.8\end{array}$ & $\begin{array}{l}107 \\
33.3\end{array}$ \\
\hline Bridges & $\begin{array}{l}46 \\
6.3\end{array}$ & $\begin{array}{c}144 \\
19.9\end{array}$ & $\begin{array}{l}155 \\
21.4\end{array}$ & $\begin{array}{c}80 \\
11.0\end{array}$ & $\begin{array}{l}309 \\
42.6\end{array}$ \\
\hline $\begin{array}{l}\text { Combined with } \\
\text { teeth }\end{array}$ & $\begin{array}{c}2 \\
1.3\end{array}$ & $\begin{array}{c}20 \\
13.1\end{array}$ & $\begin{array}{c}16 \\
10.4\end{array}$ & $\begin{array}{l}15 \\
9.8\end{array}$ & $\begin{array}{c}94 \\
61.4\end{array}$ \\
\hline $\begin{array}{l}\text { Partially abscent } \\
\text { dentition }\end{array}$ & $\begin{array}{r}164 \\
9.6\end{array}$ & $\begin{array}{l}286 \\
16.9\end{array}$ & $\begin{array}{l}406 \\
23.9\end{array}$ & $\begin{array}{l}201 \\
11.9\end{array}$ & $\begin{array}{r}643 \\
37.8\end{array}$ \\
\hline
\end{tabular}

The number of implants supporting the single crowns, being in the same condition as when installed 10 years before, was 27 (15.3\% of the implants installed); mucositis was found in 25 implants (14.2\%), bone resorption at $1 / 3$ or $1 / 2$ of the implant height was observed in 61 and 23 implants $(34.7 \%$ and $13.1 \%)$, respectively, a total of 40 implants were removed (22.7\%). The combined implant-supported crowns showed the following figures: $18.5 \%$ (15 implants), 29.6\% (24 implants), 12.4\% (10 implants), 16.1\% (13 implants), 23.5\% (19 implants). After 10 years, $15.6 \%$ of implants in the implant-supported bridges remained unchanged (17 implants), mucositis was observed in $32.1 \%$ of implants (35 implants), periimplantitis (bone resorption at $1 / 3$ or $1 / 2$ of the implant height) in $21.1 \%$ and $11.0 \%$ (23 and 12 implants), respectively, 22 implants were removed (20.2\%). In patients with bridges supported by implants and teeth, normal tissue condition was found in $5.1 \%$ of implants (2 implants), the listed above complications were revealed in 25.6\% (mucositis in 10 implants), $20.5 \%$ and $7.7 \%$ (periimplantitis at $1 / 3$ or $1 / 2$ of the implant height in 8 and 3 implants), $41.0 \%$ of implants were removed (16 implants).

After 15 years, the implant-supported partial fixed dental prostheses showed the following characteristics: no complications in $0 \%$ of implants, mucositis in $19.0 \%$ of implants (86 implants), п periimplantitis with bone resorption at $1 / 3$ of the implant height in $26.5 \%$ (120 implants), with bone resorption at $1 / 2$ in $11.5 \%$ (52 implants), $43.1 \%$ of implants were removed (195 implants). The listed above indicators in the implant-supported single crowns were $0 \%, 13.2 \%(10$ implants), 35.5\% (27 implants), 9.2\% (7 implants), 38.2\% (29 implants); in the combined implant-supported crowns these were 0\%, 17.8\% (16 implants), 32.2\% (29 implants), 10.0\% (9 implants), 40.0\% (36 implants), respectively. After the 15year loading, no implant-supported bridges preserved intact the periimplant tissue; mucositis was observed in $21.9 \%$ of implants (50 implants), periimplantitis with bone resorption at $1 / 3$ or $1 / 2$ of the implant height in $24.5 \%$ and $10.5 \%$ of implants (56 and 24 implants), 107 implants were removed (46.9\%). When combining the implant abutments and the natural teeth in bridges, the listed above characteristics were as follows: $0 \%$, 17.0\% (10 implants), 13.5\% (8 implants), 20.3\% (12 implants), $39.0 \%$ (23 implants), respectively.

After 20 years of follow-up, no implants with intact periimplant tissues were found in partial fixed dental prostheses; mucositis was found in $5.7 \%$ of implants (30 implants), periimplantitis with bone resorption at $1 / 3$ or $1 / 2$ of the implant height in $18.7 \%$ and $12.4 \%$ (98 и 65 implants), $63.1 \%$ of implants were removed (330 implants). Single and combined implant-supported crowns had the following characteristics: no complications in $0 \%$ of implants, mucositis in 3.7\% and $2.2 \%$ (4 and 2 implants), respectively, periimplantitis with bone resorption at $1 / 3$ of the implant height in $26.6 \%$ and $29.4 \%$ (29 and 27 implants), with bone resorption at 1/2 of the implant height in $18.4 \%$ and $16.3 \%$ (20 and 15 implants), 51.4\% and $52.2 \%$ of implants were removed (56 and 48 implants). After the 20-year follow-up, the implant-supported bridges together with bridges, supported by implants and teeth, showed no unchanged periimplant tissues; mucositis was observed in $9.0 \%$ and $0 \%$ of implants (24 and 0 implants), respectively, periimplantitis at $1 / 3$ of the implant height in $15.7 \%$ and $0 \%$ (42 and 0 implants), periimplantitis at $1 / 2$ of the implant height in $11.2 \%$ and $0 \%$ (30 and 0 implants), $64.1 \%$ and $100 \%$ of implants were removed (171 and 55 implants).

Summarizing the data on the condition of periimplant tissue obtained during the 20-year follow-up period regardless of the specific lifespan of the fixed prosthesis, it must be stated that no complications were observed in $9.6 \%$ of implants, mucositis in $16.8 \%$ of implants, periimplantitis with bone resorption at $1 / 3$ of the implant height in $23.9 \%$ of implants, and with bone

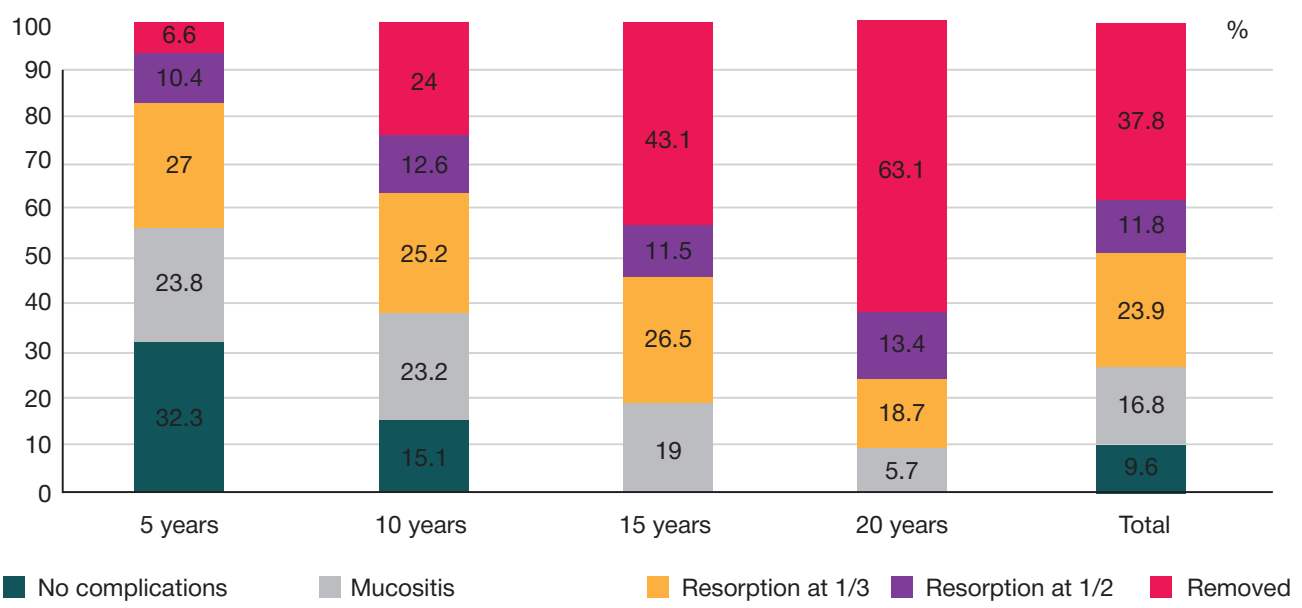

Fig. 1. Comparison of clinical and radiological dental implant assessment results for different terms from the moment of prosthetics completion 


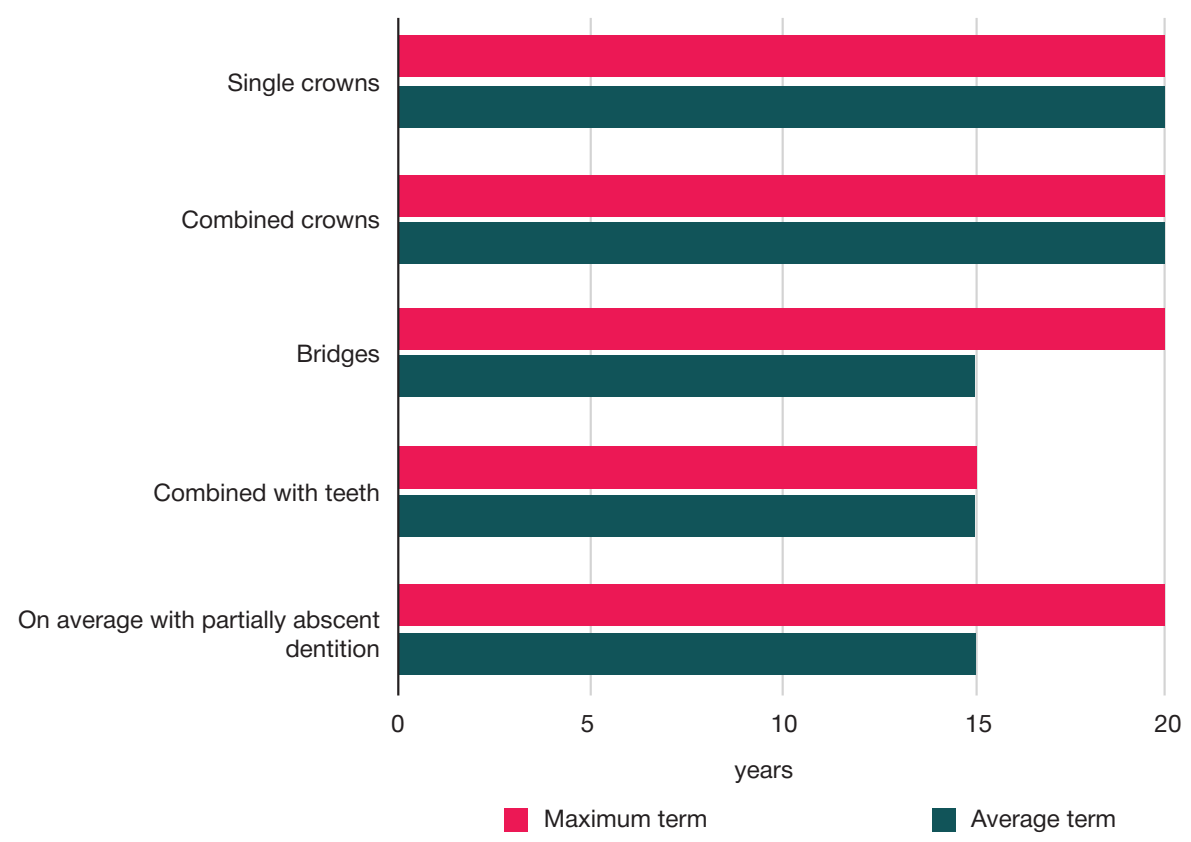

Fig. 2. Maximum and average service life of non-removable implant-based prostheses (years)

resorption at $1 / 2$ of the implant height in $11.8 \%(164,286$, 406, 201 implants, respectively); 643 implants were removed (37.8\%) (Fig. 1).

Summarizing the correlations between the periimplant tissue condition and the type of the fixed prosthesis, revealed during the whole 20-year follow-up period, it must be stated that the most effective are the implant-supported single crowns, and the least effective are the prostheses supported by implants and natural teeth (removals accounted for $26.6 \%$ and $61.4 \%$, respectively). Based on their efficiency, the implantsupported crowns and bridges are in between (33.3\% and $42.6 \%$ removed during the 20 -year period, respectively) (Table 2).

The average lifespan of the implants is defined by the time, when the patients have more than a half of implants removed. Based on the examination results, the average lifespan of the implant-supported fixed prostheses was as follows: 20 years for single and combined crowns when teeth are partially missing, and 15 years for bridges (including those supported by implants and natural teeth) (Fig. 2).

\section{DISCUSSION}

The results, obtained by assessing the large amount of clinical material, elaborate on the conflicting data on the time limits of functioning for the intraosseous implants supporting the dental prostheses. The current knowledge about the rate of implant removal, limited due to the follow-up period not exceeding 10 years, has been supplemented by the implant survival data obtained during 15-20 years of service life [6, 7, 9, 10, 13]. The significantly preserved implant-supported prostheses make it possible to support the concept of the long-term implant installation with respect to the non-removable implantsupported prostheses. The view is thus confirmed that the effectiveness of the implant-supported prosthetics is reduced with the inclusion of teeth in the bridge support, along with implants.

\section{CONCLUSIONS}

The non-removable dental prosthetics on implants used with partially abscent dentition showed high efficiency during 20 years of the partial dentition defects replacement. Regardless of the low patient compliance with the follow-up visits for professional oral hygiene or bite correction, $62.2 \%$ of implants remain functional for 20 years. The average lifespan of the implant-supported fixed prostheses is 15 years for bridges, and 20 years for single and combined crowns. Among the non-removable prostheses, the most effective are the implantsupported single crowns, and the least effective are the prostheses supported by implants and natural teeth. High rate of chronic inflammation in the periimplant zone at every stage of the prosthesis life explain the need for the strict compliance of the patients, having the implant-based prostheses installed, with the follow-up dental care.

\section{References}

1. Put VA, Solodkiy VG, Morozov PV, Olesova VN, Teplov E.V. Nine years of experience in conducting social community events for dental implantation. Russian Bulletin of Dental Implantology. 2019; (3-4): 75-81. Russian.

2. Zaslavskiy RS, Olesova VN, Shmatov KV, Ivanov AS, Zaslavskiy SA, The structure of the clinical conditions and the methods of prosthetics used in practical implantology. Dentistry for everyone. 2018; (3): 30-33. Russian.

3. Martynov DV. Experimental and clinical study of the precision of

components of dismountable dental implants [dissertation]. M., 2021. Russian.

4. French D, Kokran D, Ofek R. Retrospective cohort study of 4591 Straumann implants installed in 2060 patients in private practice, with follow-up for up to 10 years: relationship between the level of the bone of the alveolar ridge and the state of soft tissues. PERIO IQ. 2017; (28): 22-42.

5. Sakaeva ZU, Zaslavskiy RS, Remizova AA, Ragulin AV, Popov AA, Olesov EE. Clinical and microbiological substantiation of the 
frequency of professional oral hygiene during implant treatment. Russian Bulletin of Dental Implantology. 2020; (3-4): 79-83. Russian.

6. Bersanov RU. Functional and economic efficiency of modern methods orthopedic rehabilitation of patients with partial and complete adentia [dissertation]. M., 2016. Russian.

7. Povstyanko YuA. Comparative study of modern dental implants: experimental clinical and technological aspects [dissertation]. M., 2018. Russian.

8. Zucchelli G, Tavelli L, Stefanini M. Classification of facial periimplant soft tissue dehiscence/deficiencies at single implant sites in the esthetic zone. J Periodontol. 2019; 90 (10): 1116-24.

9. Shi JY, Xu FY, Zhuang LF, Gu YX, Qiao SC, Lai HC. Longterm outcomes of narrow diameter implants in posterior jaws: A retrospective study with at least 8-year follow-up. Clin Oral Implants. 2018; 29 (1): 76-81.

10. Ma M, Qi M, Zhang D, Liu H. The clinical performance of narrow diameter implants versus regular diameter implants: A systematic review and meta-analysis. Clin Oral Implant Res. 2018; 29 (1): 100-7.

11. Long L, Alqarni H, Masri R. Influence of implant abutment

\section{Литература}

1. Путь В. А., Солодкий В. Г., Морозов П. В., Олесова В. Н., Теплов Е. В. Девятилетний опыт проведения социальных общественных мероприятий по дентальной имплантации. Российский вестник дентальной имплантологии. 2019; (3-4): 75-81.

2. Заславский Р. С., Олесова В. Н., Шматов К. В., Иванов А. С., Заславский С. А. Структура клинических условий и используемых методов протезирования в практической имплантологии. Стоматология для всех. 2018; (3): 30-33.

3. Мартынов Д. В. Экспериментально-клиническое исследование прецизионности компонентов разборных дентальных имплантатов [диссертация]. М., 2021.

4. Френч Д., Кокран Д., Офек Р. Ретроспективное когортное исследование 4591 имплантата системы Straumann, установленных у 2060 пациентов в частной практике, с наблюдением до 10 лет: взаимосвязь уровня кости альвеолярного гребня и состояния мягких тканей. PERIO IQ. 2017; (28): 22-42.

5. Сакаева З. У., Заславский Р. С., Ремизова А. А., Рагулин А. В., Попов А. А., Олесов Е. Е. Клинико-микробиологическое обоснование периодичности профессиональной гигиены рта на протяжении имплантологического лечения. Российский вестник дентальной имплантологии. 2020; (3-4): 79-83.

6. Берсанов Р. У. Функциональная и экономическая эффективность современных методов ортопедической реабилитации больных с частичной и полной адентией [диссертация]. М., 2016.

7. Повстянко Ю. А. Сравнительное исследование современных дентальных имплантатов: экспериментально-клинические и технологические аспекты [диссертация]. М., 2018.

8. Zucchelli G, Tavelli L, Stefanini M. Classification of facial periimplant soft tissue dehiscence/deficiencies at single implant sites in the esthetic zone. J Periodontol. 2019; 90 (10): 1116-24. fabrication method on clinical outcomes: a systematic review. Eur J Oral Implantol. 2017; 10 (1): 67-77.

12. Heitz-Mayfield LJA., Salvi GE. Peri-implant mucositis. J Clin Periodontol. 2018; 45 (20): 237-45.

13. Tsitsiashvili AM, Panin AM, Volosova EV. The success of treatment and the survival rate of dental implants in different approaches to the treatment of patients using dental implants in conditions of a limited bone tissue volume. Russian Dental Journal. 2020; (1-2): 32-38. Russian.

14. Bulycheva EA, Trezubov VV. Preliminary dental prosthetics. A guide for dentists. St. Petersburg: Man, 2019; 92 p. Russian.

15. Trezubov VN, Arutyunov SD, editors. Clinical dentistry. Hospital course. In 6 t. m.: Practical medicine, 2020; 1688 p. Russian.

16. Kulakov AA, editor. Surgical dentistry and maxillofacial surgery. National leadership. M.: GEOTAR-Media, 2015; 928 p. Russian.

17. Kulakov AA, editor. Dental implantation. National guidelines $M$.: GEOTAR-Media, 2018; 400 p. Russian.

18. Lebedenko IYu, Arutyunov SD, Ryakhovskiy AN, editors. Prosthetic Dentistry. National Guidelines. M.: GEOTAR-Media, 2016; 824 p. Russian.

9. Shi JY, Xu FY, Zhuang LF, Gu YX, Qiao SC, Lai HC. Longterm outcomes of narrow diameter implants in posterior jaws: A retrospective study with at least 8 -year follow-up. Clin Oral Implants. 2018; 29 (1): 76-81.

10. Ma M, Qi M, Zhang D, Liu H. The clinical performance of narrow diameter implants versus regular diameter implants: A systematic review and meta-analysis. Clin Oral Implant Res. 2018; 29 (1): 100-7.

11. Long L, Alqarni H, Masri R. Influence of implant abutment fabrication method on clinical outcomes: a systematic review. Eur J Oral Implantol. 2017; 10 (1): 67-77.

12. Heitz-Mayfield LJA., Salvi GE. Peri-implant mucositis. J Clin Periodontol. 2018; 45 (20): 237-45.

13. Цициашвили А. М., Панин А. М., Волосова Е. В. Успешность лечения и выживаемость дентальных имплантатов при различных подходах к лечению пациентов с использованием дентальных имплантатов в условиях ограниченного объема костной ткани. Российский стоматологический журнал. 2020; (1-2): 32-8.

14. Булычева Е. А., Трезубов В. В. Предварительное зубное протезирование. Руководство для врачей-стоматологов. СПб. Человек, 2019; 92 с.

15. Трезубов В. Н., Арутюнов С. Д., редакторы. Клиническая стоматология. Госпитальный курс. В 6 т. М.: Практическая медицина. 2020; 1688 с.

16. Кулаков А. А., редактор. Хирургическая стоматология и челюстно-лицевая хирургия. Национальное руководство. М.: ГЭОТАР-Медиа, 2015; 928 с.

17. Кулаков А. А., редактор. Дентальная имплантация. Национальное руководство. М.: ГЭОТАР-Медиа, 2018; 400 с.

18. Лебеденко И. Ю., Арутюнов С. Д., Ряховский А. Н., редакторы. Ортопедическая стоматология. Национальное руководство. М.: ГЭОТАР-Медиа, 2016; 824 с. 